\title{
POTRET KEBERHASILAN PEMBELAJARAN PENDIDIKAN AGAMA ISLAM DI MADRASAH ALIYAH
}

\author{
Sumarni \\ Peneliti Muda Puslitbang Pendidikan Agama dan Keagamaan \\ Badan Litbang dan Diklat Kementerian Agama RI \\ Jl. MH Thamrin No. 06 Jakarta Pusat \\ Email: marni_ch@yahoo.com.au /Hp 0817859942
}

\begin{abstract}
The practice of Islamic learning education (PAI) in madrasah aliyah (MA) is expected to become holistic, systematic, integrated, and capable in combining cognitive, affective, and psychometric objectives. The educational process is to create students with strong faith, high moral fiber, polite personality, dedicated, humble, possessing a holistic intellectuality, individually and socially religious, emotionally mature, and modest. This research exists to identify the teaching implementation of Islam education in MA. Specifically, this paper is to distinguish the development level of success in teaching PAI in MA. The result of this research indicates that the level of MA students in achieving cognitive learning in PAI is relatively well with the score of 78 to 80 . The achievement from the psychometric level is measured by 3 well-behave aspects inevitably by the religious practices, however, there are still 2 among the students which still need guidance. Based on the affective aspect, five of the PAI issue studies are still considered unsuccessful. Factors that applies the success of PAI teachings include; the quality of the madrasah, behavior of the teachers, routine of the host families, and so on.
\end{abstract}

Keyword: learning success, Islamic education, madrasah aliyah

\begin{abstract}
Abstrak
Praktik pembelajaran pendidikan agama Islam (PAI) di Madrasah Aliyah (MA) seharusnya dilakukan secara holistik, sistematis dan integral, serta mampu memadukan target capaian kognitif, afektif dan psikomotorik. Proses pendidikan agama di madrasah diharapkan mampu melahirkan peserta didik yang beriman dan bertakwa, bermoral tinggi, berkepribadian yang sopan, ramah, bermartabat, berakhlak mulia, serta memiliki intelektualitas yang tinggi secara holistik, saleh di ranah individual dan sosial, dewasa secara emosional, serta santun secara sosial. Penelitian ini untuk mengetahui bagaimana implementasi pembelajaran pendidikan Agama Islam di MA. Secara khusus penelitian ini dilakukan untuk mengetahui bagaimana tingkat keberhasilan PAI di MA dan faktor apa saja yang mempengaruhi tingkat keberhasilan pembelajaran PAI di MA. Hasil penelitian ini menunjukkan bahwa hasil capaian kognitif siswa MA dalam pembelajaran PAI relatif sudah cukup baik dengan nilai 78 sampai 80. Hasil capaian aspek psikomotorik diukur dari 3 aspek perilaku juga cukup baik, terutama dalam ritual ibadah keagamaan, namun pada 2 aspek perilaku siswa laianya masih perlu perbaikan. Pada hasil capaian aspek afektif dilihat dari lima rumpun bidang isu pelajaran PAI masih kurang berhasil. Beberapa faktor ikut mempengaruhi tingkat keberhasilan pembelajaran PAI di MA, seperti kualitas madrasah, sikap keagamaan guru, pola asuh orang tua, dan sebagainya.
\end{abstract}

Kata Kunci: keberhasilan pembelajaran, pendidikan agama Islam, madrasah aliyah 


\section{PENDAHULUAN}

Pemerintah Indonesia sangat memperhatikan pendidikan agama dan keagamaan. Pendidikan agama, secara konstitusional, adalah hak setiap warga negara. Hal ini sesuai dengan amanat legal Pasal 12 (1-a) UUSPN. Pasal dimaksud menegaskan bahwa setiap peserta didik pada setiap satuan pendidikan berhak mendapatkan pendidikan agama sesuai dengan agama yang dianutnya dan diajarkan oleh pendidik yang seagama. Di sini, pendidikan agama Islam (PAI) selain untuk memenuhi amanat konstitusional, ia dimaksudkan sebagai program yang terrencana untuk menyiapkan peserta didik guna mengenal, memahami, mengimani, menghayati, dan mengamalkan ajaran Islam. Lebih jauh, pembelajaran PAI ditargetkan guna mampu menanamkan kesadaran dan pembiasaan perilaku keagamaan pada diri peserta didik muslim, terutama di ranah kehidupan bermasyarakat, berbangsa dan bernegara. Hasilnya adalah mereka diharapkan dapat menghayati dan mengamalkan ajarannya, dan menghormati hak-hak pemeluk agama lain, serta dapat hidup damai, harmonis berdampingan dengan sesama warga Indonesia dalam perbedaan dan kebersamaan. Tuntutan praktis ini adalah implikasi dari realitas yang tak terrelakkan dari dimensi kehidupan keagamaan di ranah keragaman dan kerukunan antar umat beragama. ${ }^{1}$

PAI di lingkungan madrasah merupakan suatu upaya, dan proses mendidik peserta didik untuk mengetahui, memahami, menghayati, dan sekaligus mengamalkan ajaran dan nilai-nilai luhur Islam. Dengan kata lain, PAI bertujuan untuk mendidik setiap peserta didik agar beriman, bertakwa, dan beribadat dengan baik kepada Allah SWT, sehingga dia memperoleh kebahagiaan duniawi dan ukhrawi. Tujuan PAI di atas, secara sinergis, untuk mendukung arah dan pencapaian tujuan pendidikan nasional

${ }^{1}$ Muhammad Alim. 2006. Pendidikan Agama Islam, Upaya Pembentukan Pemikiran dan Kepribadian Muslim. Bandung: PT Remaja Rosdakarya. h. 6. seperti diamanatkan oleh Pasal 3 Bab II UUSPN, yang menegaskan bahwa pendidikan nasional bertujuan untuk pengembangan potensi peserta didik agar menjadi manusia yang beriman dan bertaqwa kepada Tuhan Yang Maha Esa, berakhlak mulia, sehat, berilmu, cakap, kreatif, mandiri dan menjadi warga negara yang demokratis serta bertanggungjawab.

Isi beberapa pasal UUSPN di atas mengindikasikan posisi yang signifikan dan strategis PAI dalam media dan proses pembentukan karakter bangsa, terutama generasi muda. Orientasi pelaksanaannya bukan hanya pada pengembangan kualitas IQ (kecerdasan intelektual), tetapi sebagai perpaduan IQ, dengan EQ (kecerdasan emosional) dan SQ (spiritual) secara simbiosis. Untuk merujuk pesan dalam pasal-pasal di atas, proses pendidikan di madrasah diharapkan mampu melahirkan peserta didik yang beriman dan bertakwa, bermoral tinggi, berkepribadian yang sopan, ramah, bermartabat, berakhlak mulia, serta memiliki intelektualitas yang tinggi; secara holistik, saleh di ranah individual, komunal, sosial, dan publik; serta dewasa secara emosional, dan santun secara sosial.

Pembelajaran PAI di Madrasah Aliyah (MA) harus dilakukan secara holistik, sistematis dan integral, serta diharapkan mampu memadukan targetcapaian kognitif, afektif dan psikomotorik. Pada kenyataannya, praktik PAI di MA masih variatif, dan hasilnya masih belum maksimal, karena model pengajaran PAI masih sangat menekankan capaian kognitif. Idealnya, PAI di MA lebih banyak ditekankan pada penghayatan, internalisasi, dan pengamalan ajaran agama dalam kehidupan sehari-hari. Pembelajaran PAI tidak hanya sebatas retorika ilmiah-verbalis. Pada target maksimal, keberhasilan seorang anak didik pada pelajaran PAI, seharusnya, tidak hanya diukur dengan sebatas pertimbangan standar capaian kognitif (pengetahuan). Hal yang terpenting justru adalah seberapa maksimal seluruh dimensi capaian ranah kognitif tersebut telah dihayati, disikapi positif (afektif), dan diamalkan (psikomotorik) oleh peserta didik dalam 
kehidupan nyata, baik di level individu, anggota keluarga, masyarakat dan warga negara. Di sini, perpanduan hasil capaian kognitif, afektif dan psikomotorik menjadi sangat penting, agar via hasil PAI, Islam dapat lebih menjadi agama praksis. Dengan demikian, peserta didik Islam memiliki pengetahuan, sikap kecenderungan, dan perilaku islami dalam kehidupan seharihari. Dengan kata lain, potret perilaku nyata di level kehidupan sehari-hari adalah penting untuk dijadikan sebagai satu indikator untuk menilai keberhasilan PAI di MA pada peserta didik.

PAI di MA oleh banyak pihak dikiritk dan dinilai masih belum berhasil, jika diukur dengan standar perpaduan capaian kognitif, afektif dan psikomotorik. Harus dicamkan bahwa saat ini, masyarakat umum sangat menaruh harapan besar terhadap peran MA melalui pembelajaran PAI, sesuai dengan tugas pokok dan fungsinya, untuk menyiapkan peserta yang intelek, bermoral, dewasa dan santun secara sosial, bermartabat, dan berakhlak mulia di ranah personal. Di sini, peran MA diharapkan mampu menjawab tantangan kemajuan ilmu pengetahuan dan teknologi, tanpa harus kehilangan identitas luhur keagamaan, dan fungsi primernya sebagai lembaga pendidikan formal yang berbasis agama. MA juga diharapkan bisa membekali peserta didik dengan pendidikan agama dan keagamaan.

Kritik terhadap keberhasilan pembelajaran PAI adalah menarik untuk dievaluasi tingkat keberhasilan pembelajaran PAI di MA. "Bagaimana hasil capaian pembelajaran PAI pada peserta didik di MA?" Karena itu, Pusat Penelitian dan Pengembangan Pendidikan Agama dan Keagamaan, Kementerian Agama Tahun Anggaran 2012 melakukan survei tentang keberhasilan pembelajaran PAI di MA di 16 provinsi yang menjadi basis utama PAI dengan beragam karakter lokalnya. Pemilihan MA sebagai fokus survei didasarkan pada pemikiran bahwa MA merupakan jenjang pendidikan menengah tertinggi yang lulusannya diharapkan telah memiliki kompetensi yang lebih utuh di bidang agama Islam sebagai hasil dari pembelajaran PAI dari tingkat dasar hingga menengah.

Permasalahan survei ini adalah hasil pembelajaran PAI di MA pada peserta didik. Adapun pertanyaan penelitiannya adalah: 1) Bagaimana tingkat keberhasilan pembelajaran PAI di MA, dan 2) Faktor-faktor apa saja yang mempengaruhi keberhasilan pembelajaran PAI di MA?

Tujuan survei ini adalah untuk: 1) Mengetahui tingkat keberhasilan PAI di MA, dan 2) Mengetahui faktor-faktor yang mempengaruhi tingkat keberhasilan PAI di MA. Secara praktis, hasil penelitian ini diharapkan dapat dijadikan bahan masukan bagi para praktisi dan pemangku kebijakan pendidikan Islam untuk membenahi pembelajaran PAI di MA. Hal ini penting mengingat bahwa perencanaan, kebijakan dan praktek pembelajaran PAI di madrasah-madrasah, tepatnya di institusi pendidikan Islam, baik modern atau tradisional, selama ini, masih belum begitu kuat mengacu pada hasil studi empiris. Dengan kata lain, hasil penelitian ini, sedikit-banyak, dapat memberi pijakan empiris dan strategis bagi kebijakan yang lebih kuat, valid dan reliabel untuk merancang bangun dan mengevaluasi hasil PAI di MA. Secara akademis, hasil penelitian ini diharapkan dapat dijadikan dasar bagi praktisi dan pakar pendidikan agama untuk menyusun dan mengembangkan serangkaian konsep pendidikan, pembelajaran, serta strategi, media dan teknik pengajaran PAI. Hal ini sangat bermakna mengingat bahwa guru PAI, umumnya, masih cenderung menggunakan model dan strategi pembelajaran konvensional dalam mengajar materi agama Islam. Hasil studi ini diharapkan dapat memberi satu pijakan ilmiah untuk rancang bangun materi, pendekatan, metode, strategi dan teknik pengajaran dan pembelajaran PAI di MA. 


\section{KERANGKA KONSEPTUAL}

\section{Pengertian Pendidikan Agama Islam (PAI)}

Pendidikan adalah usaha sadar dan sengaja yang dirancang untuk mencapai tujuan yang ditetapkan, ${ }^{2}$ atau sebagai usaha manusia guna menumbuhkembangkan potensi pembawaan baik jasmani maupun rohani, sesuai dengan nilai-nilai luhur, yang ada di masyarakat. Sementara itu, PAI didefinisikan sebagai upaya untuk mengaktualisasikan sifat-sifat dasar kesempurnaan yang dianugerahkan Allah pada manusia. ${ }^{3}$ Rangkaian usaha tersebut harus dilaksanakan dengan dedikatif, optimal, ikhlas, dan semata-mata beribadat pada Allah. Di sini, PAI merupakan proses penyampaian informasi, ilmu dalam rangka pembentukan insan yang beriman dan bertakwa, agar dia menyadari kedudukan, tugas dan fungsi utamanya di dunia dengan selalu memelihara relasinya dengan Allah, diri sendiri, masyarakat dan alam sekitarnya, serta tanggungjawabnya kepada Allah.

Di sisi lain dirumuskan bahwa PAI adalah rangkaian kegiatan sistematis dan terrencana untuk mengubah tingkah laku individu peserta didik pada kehidupan pribadi, masyarakat dan alam sekitarnya. Di sini terlihat bahwa PAI pada dasarnya adalah pendidikan yang bertujuan untuk membentuk pribadi muslim seutuhnya, mengembangkan seluruh potensi manusia dalam wujud jasmani dan rohani. ${ }^{4}$ A.Qodri Azizy menegaskan dua unsur subtansial dari pelaksanaan PAI, yaitu (1) mendidik peserta didik untuk mempelajari ajaran Islam, dan (2) mendidik peserta didik untuk berperilaku sesuai dengan nilai-nilai dan akhlak Islam. ${ }^{5}$

Dari deskripsi di atas, dapat dirumuskan bahwa hal yang dimaksud dengan PAI adalah suatu proses dan tindakan yang dilakukan

\footnotetext{
2 P.A. Sahertian. 2000. Konsep Dasar dan Teknik Supervisi Pendidikan. Jakara: Rineka Cipta.

${ }^{3}$ Imama Bawani. 1993. Ilmu Pendidikan Islam. Jakarta: Bumi Aksara.

${ }^{4}$ Seperti dikutip oleh Haidar Putra Daulay. 2004. Pendidikan Islam, Jakarta: Kencana. h. 153.

${ }^{5}$ A. Qodri Azizy. 2000. Islam dan Permasalahan Sosial: Mencari Jalan Keluar. Yogjakarta: Pustaka Pelajar.
}

secara sadar dan terrencana untuk mengajarkan agama Islam guna mengubah tingkah laku yang mengarah pada pembentukan kepribadian anak didik yang sesuai dengan norma-norma yang ditentukan ajaran agama Islam.

\section{Keberhasilan Pendidikan Agama Islam (PAI)}

Hasil merupakan perolehan sebagai akibat dari pelaksanaan suatu aktivitas atau proses yang kemudian mengubah input secara fungsional. Pencapaian hasil PAI seorang siswa bisa dilihat dari anasir capaian kognitif, sikap dan perilakunya, yaitu dalam bentuk penguasaan pengetahuan, model penyikapan terhadap isu-isu keagamaan Islam yang diajarkan, ketrampilan berpikir, serta ketrampilan motorik bidang materi ajar PAI. Perlu juga ditambahkan bahwa hasil pembelajaran PAI adalah hal yang dapat dipandang dari dua sisi yaitu perspektif peserta didik, dan guru. ${ }^{6}$ Dari sisi pertama, hasil belajar merupakan tingkat capaian perkembangan mental yang lebih baik, bila dibanding saat sebelum belajar. Tingkat perkembangan mental dimaksud terwujud pada ranah kognitif, afektif, dan psikomotor. Dari sisi guru, hasil belajar terukur dengan standar terselesaikannya bahan pelajaran dalam proses pengajaran.

Menurut Oemar Hamalik, keberhasilan belajar terukur dengan perubahan sikap dan perilaku yang terjadi pada peserta didik pada aspek materi ajar, misalnya dari tidak tahu menjadi tahu, dari tidak paham menjadi paham, dari paham menjadi menghayati, terus melakukannya, dari aspek mencoba menjadi membiasakan. Ringkasnya, ada tiga anasir hasil belajar, yaitu pengetahuan, sikap kecenderungan, dan ketrampilan dan kebiasaan dalam melaksanakan muatan materi ajar. ${ }^{7}$ Konsep ini menunjukkan bahwa hasil pembelajaran PAI harus terukur dengan fakta

6 Dimyati dan Mudjiono. 2006. Belajar dan Pembelajaran. Jakarta: Rieneke Cipta.

7 Oemar Hamalik. 2004. Proses Belajar Mengajar. Jakarta: Bumi Aksara. 
perubahan (sikap dan perilaku) yang dinamis terjadi pada diri peserta didik.

Secara ringkas, sesuai dengan tujuan dasarnya, keberhasilan pembelajaran PAI di MA mencakup tiga ranah capaian, yaitu unsur kognitif, afektif (sikap-penghayatan) dan psikomotorik (perilaku keagamaan). Dalam studi ini, keberhasilan dirumuskan sebagai hasil capaian suatu program terrencana, yang terukur secara kuantitatif dengan standar acuan numerik. Keberhasilan pembelajaran PAI dilihat dari capaian kognitif, sikap dan perilakunya, yaitu dalam bentuk penguasaan pengetahuan, model penyikapan terhadap isu-isu keagamaan Islam yang diajarkan, ketrampilan berpikir, serta ketrampilan motorik bidang materi ajar PAI. Ranah keberhasilan kognitif diukur dengan nilai akhir semester ganjil-genap tahun akademik 2011-2012, sebagai hasil capaian siswa per satuan mata pelajaran PAI. Sementara nilai keberhasilan di ranah afektif dan psikomotorik juga diukur dengan skala numerik. Kualitas validitas dan reliabilitas instrumen penelitian ini telah diuji berdasar hasil ujicoba instrumen pengumpulan data

\section{Faktor yang Mempengaruhi Keberhasilan Pembelajaran PAI}

Lulusan dan peserta didik MA dituntut memiliki wawasan ilmu agama yang mendalam di level kognitif, santun, ramah dan dewasa di ranah afektif dan psikomotorik dalam kehidupan keagamaan. Namun faktanya, banyak kritik terhadap keberhasilan PAI di MA. Kritik ini, nampaknya terkait dengan model pembelajaran PAI di MA. ${ }^{8}$ Pertama, materi pelajaran agama Islam sampai saat ini cenderung diajarkan sebatas hafalan, padahal ajaran Islam sarat dengan nilai-nilai yang harus dihayati dan dipraktekkan. Kedua, PAI lebih ditekankan pada relasi formal antara hamba dengan Tuhannya, sebaliknya penghayatan terhadap nilai-nilai dasar agama kurang ditekankan. Di ranah ritual formal, fungsi agama sering kehilangan sentuhan

${ }^{8}$ M. Arifin. 1991. Kapita Selekta Pendidikan (Islam dan Umum). Jakarta: Bumi Aksara,. h. 96-100;. spiritual. Ketiga, penalaran dan argumentasi penyelesaian isu-isu keagamaan aktual kurang mendapat perhatian yang memadai. Keempat, orientasi beragama di ranah penghayatan terhadap lingkungan kehidupan sosial masih sangat rendah. Kelima adalah parsialitas kebijakan dan keterbatasan perhatian pemangku kebijakan dan praktisi pendidikan agama terhadap model, strategi dan metode PAI yang lebih efektif dan efisien. Keenam, ukuran keberhasilan PAI masih sebatas standar kognitif. Terakhir, hasil PAI belum secara khusus dijadikan sebagai indikator krusial dalam pendidikan karakter anak didik dalam perilaku keseharian.

Kritik lain menegaskan bahwa kekurangberhasilan pembelajaran PAI terutama di MA disebabkan oleh beberapa faktor lain. Faktorfaktor tersebut anatara lain keterbatasan waktu pembelajaran, materiajar PAIyanglebihterfokus pada model pengayaan pengetahuan, minim dalam pembentukan sikap dan pembiasaan dan habituasi, keterbatasan porsi partisipasi guru mata pelajaran lain dalam memberi motivasi, memantau, dan mengawal peserta didik dalam mempraktekkan nilai-nilai agama dalam kehidupan sehari-hari. Faktor penyebab lainnya adalah titik lemah kualitas sumberdaya guru PAI dalam pengembangan pendekatan, strategi, metode, dan teknik yang lebih variatif dalam pengajaran PAI, keterbatasan partisipasi aktif para orangtua, kekurangan berbagai sarana dan prasarana pelatihan dan pengembangan strategi, metode, teknik dan media belajarmengajar PAI. ${ }^{9}$

Kekurang-berhasilan PAI nampaknya juga disebabkan faktor orientasi dan pemahaman konsep PAI yang kurang tepat. Di sini, ada 2 kritik lain terhadap orientasi PAI, yaitu (1) pembelajaran PAI tidak memiliki strategi penyusunan dan pemilihan materi yang tepat, akibatnya terjadi kerancauan, miminal tumpang-

${ }^{9}$ Departemen Pendidikan Nasional. 2002. Kurikulum dan Hasil Belajar Kompetensi Dasar Mata Pelajaran Agama Islam di Sekolah Menengah Atas dan Madrasah Aliyah. Jakarta: Pusat Kurikulum, Balitbang, Depdiknas. h. 6; 
tindih materi ajar PAI, dan (2) keterbatasan pengembangan materi ajar PAI yang lebih luas, holistik, dan mendalam, serta kurangnya penugasan prinsip kunci dan pokok materi agama kepada peserta, sehingga tidak sesuai dengan semangat dan konteks pesan luhur agama. ${ }^{10}$

Mengacu pada kerangka teori dan kritik di atas, secara ringkas, ada dua variabel utama yang dalam penelitian ini diteoritisasikan menentukan hasil pembelajaran PAI di MA, yaitu faktor internal dan eksternal MA. Faktor internal MA mencakup faktor guru dengan rincian turunannya; kualitas MA, sistem pengelolaan siswa, hidden dan ekstra-kurikuler. Faktor guru mencakup kegiatan pedagogisnya di kelas dalam proses kegiatan belajar-mengajar dan sikap dan perilaku sosial keagamaannya. Sedang faktor eksternal MA mencakup konteks geografis, demografis dan lingkungan sosial MA, serta lingkungan keluarga siswa (status sosialekonomi, dan pola asuh sosial-keagamaan).
Selanjutnya, berdasarkan kerangka teoritis, mekanisme alur logis kerja variabel penelitian ini adalah disajikan pada Bagan 1. Variabel $Y$ adalah tingkat keberhasilan pembelajaran PAI yang dipilah ke dalam 3 ranah (kognitif, afektif, dan psikomotorik) dengan skala pengukuran yang telah dijelaskan. Sedang variabel independen (internal) adalah X1 (keberadaan MA, mencakup status hukumakreditasi) MA, prestasi siswa MA, aktivitas sosial-keagamaan MA, dan sistem pengelolaan siswa), dan X2 (proses belajar-mengajar guru PAI, dan sikap dan kegiatan sosial-keagamaannya). Variabel kontrolnya adalah pola asuh orangtua, lingkungan sosial-geografis-demografis MA.

\section{Metode Penelitian}

Penelitian ini dilakukan di 16 propinsi, yaitu: (1) Daerah Istimewa Nangroe Aceh Darussalam,

Bagan 1: Mekanisme Interaksi Fungsional Variabel Penelitian Hasil Pembelajaran Pendidikan Agama Islam di MA

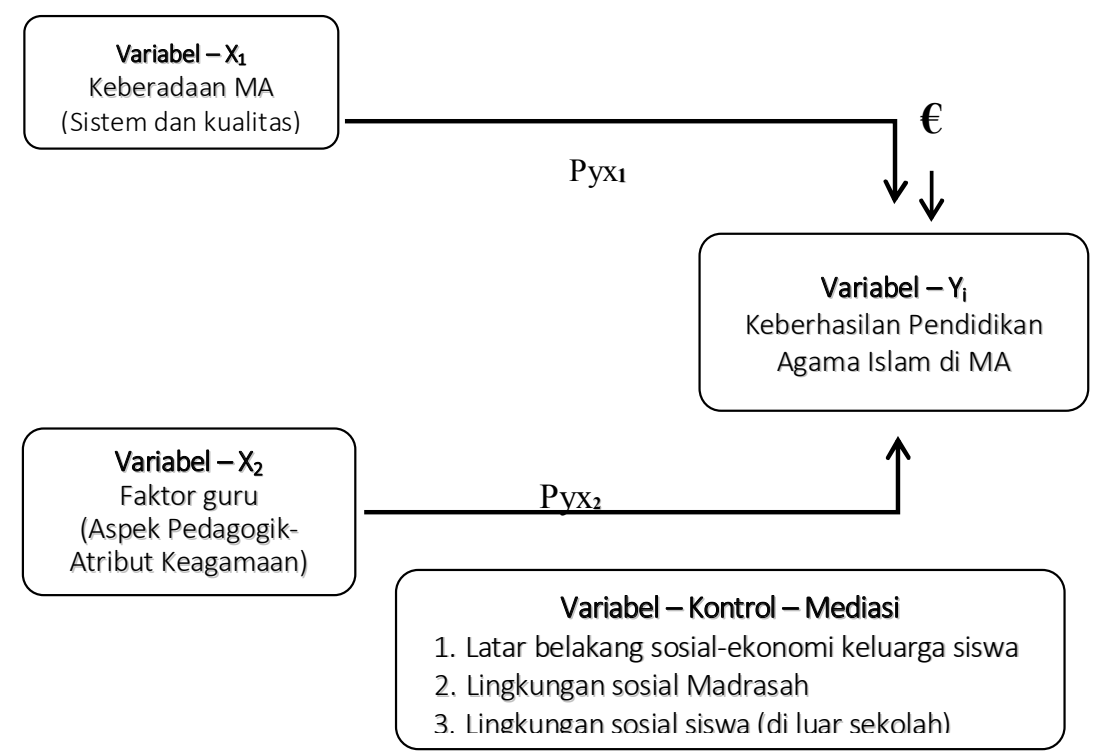

10 Mukhtar. 2003. Desain Pembelajaran Pendidikan Agama Islam. Jakarta: Miska Galiza. h.21; Nyayu Khodijah. 2009. "Peningkatan Keberhasilan Pembelajaran PAI di SMA dengan Pendekatan Belajar Reflektif', Jurnal Teknologi Pendidikan, Vol 9, No. 3. , h. 171. 
(2) Sumatera Utara, (3) Sumatera Barat, (4) Riau, (5) Lampung, (6) DKI Jakarta, (7) Jawa Barat, (8) Jawa Tengah (plus Sleman D.I. Yogyakarta), (9) Jawa Timur, (10) Bali, (11) Nusa Tenggara Barat, (12) Kalimantan Barat, (13) Kalimantan Selatan, (14) Sulawesi Tengah, (15) Sulawesi Selatan, (16) Maluku.

Populasi penelitian ini adalah seluruh peserta didik dan guru PAI MA yang berada di wilayah survei. Sedang populasi sasaran adalah seluruh peserta didik MA kelas XI dan XII dan guru PAI yang mengajar di kelas X, XI dan XII MA yang menjadi target penelitian. Selain peserta didik dan guru PAI, survei juga melibatkan partisipasi narasumber lain, yaitu pimpinan dan staf administrasi MA. Kelompok terakhir ini diminta memberi data tentang kelembagaan MA.

\footnotetext{
$\mathrm{n}=\frac{N}{1+N \sigma^{2}} \quad$ atau sampel $=\left[\frac{5.419}{1+5.419 \times 0.05^{2}}\right]=369$ madrasah

Keterangan : $n=$ Besaran sampel

$\mathrm{N}=$ Besaran populasi

$\mathrm{E}=$ Nilai kritis yang ditetapkan (\% error) karena salah penarikan sampel)
}

Ketika survei ini berusaha mengestimasi karakter populasi MA dengan tingkat signifikansi $95 \%$, dan kesalahan pencuplikan sampel $5 \%$, dengan rumus Slovin, jumlah sampel normatif untuk penelitian adalah 369 MA. Untuk kepentingan analisis, sebaran sampel survei untuk MAN dilebihkan, menjadi 84 buah, dan 285 MAS. Pengurangan proporsi jumlah sampel MAS didasarkan pada fakta sifat homogenitas MAS. Sampel MA bervariasi menurut jumlah MA di wilayah survei terhadap jumlah total MA di provinsi survei.

Prosedur penentuan-seleksi sampel dan sebaran sampel menurut provinsi, kabupatenkota, status MA, dan sampel siswa dan guru adalah sebagai berikut:

a. Sampel diseleksi dengan menggunakan teknik random berjenjang (multi-stage random sampling). Pada level penentuan kabupaten-kota, wilayah survei dirumpun (clustered) mengacu pada regional cluster kabupaten-kota. Di sini, sebaran daerah kabupaten-kota yang sangat variatif diusahakan terwakili, mengingat secara kultural dan tradisi keagamaan, daerahdaerah tersebut memiliki keunikan tersendiri. Untuk itu, pemilihan kotakabupaten sangat mempertimbangkan faktor sebaran wilayah.

b. Di tahap berikutnya, populasi distratifikasi mengacu pada pertimbangan faktor teoritis, yang diyakini mempengaruhi hasil capaian pembelajaran PAI. Di level ini, populasi MA dipilah ke dalam kategori (a) status hukum (negeri-swasta), dan (b) status akreditasi (belum-sudah terakreditasi dengan rinciannya). Pada tahap ini, sampel MA diseleksi dengan menggunakan prosedur simple random sampling.

1) Sampel Siswa. Di setiap MA diseleksi 10 orang siswa secara random. Masingmasing kelas (XI dan XII) diseleksi 5 orang siswa. Sampel siswa per kelas diseleksi dengan systematic random sampling berbasis daftar hadir siswa. Karena jumlah siswa per kelas rata-rata berkisar antara 25-35 orang, sampel siswa dipilih dengan menggunakan angka kelipatan 7 (diasumsikan 30:4=7).

2) Sampel Guru. Jika guru PAI di MA terpilih hanya ada empat orang, semua guru tersebut langsung ditetapkan sebagai sampel. Jika di MA yang terpilih ada lebih dari 4 orang guru, seleksi sampel guru harus memperhatikan representasi guru menurut setiap mata pelajaran PAI. Jika ada beberapa guru untuk satu pelajaran PAI, maka sampel diseleksi dengan sistem pengundian. Jika di MA hanya ada satu atau dua orang guru PAI, hanya guru-guru tersebut yang dijadikan responden.

Instrumen pengumpulan data terdiri atas tiga unit, yaitu dua kuesioner, dan satu daftar isian. Kuesioner pertama untuk pengumpulan data yang terkait dengan siswa, dan kuesioner kedua untuk data guru. Instrumen ketiga 
adalah daftar isian untuk mendapatkan datainformasi tentang kelembagaan MA.

\section{HASIL DAN PEMBAHASAN}

\section{Hasil Capaian Kognitif}

Capaian kognitif bervariasi menurut status MA, bidang pelajaran dan semester. Pertama, capaian nilai siswa untuk semua pelajaran PAI semester ganjil baru mencapai standar cukup baik, di level antara 78-80). Sementara itu, hasil capaian semester genap relatif lebih baik untuk semua pelajaran. Nilai kognitif siswa MAN sudah mencapai taraf BAIK (8190), kecuali untuk pelajaran SKI. Kedua, hasil capaian kognitif pelajaran al-Quran-Hadis dan Fikih di atas rata-rata hasil capaian pada dua pelajaran lainnya, yaitu Akidah-Akhlak dan SKI. Ketiga, hasil capaian kognitif siswa MAN selalu lebih tinggi dibanding dengan hasil capaian kognitif siswa MAS. Keempat, hasil capaian nilai semester genap selalu lebih tinggi dibanding dengan hasil capaian siswa pada nilai semester ganjil untuk seluruh bidang pelajaran PAI.

Tabel 1:

Statistik Kelompok Nilai Siswa MA menurut Pelajaran PAI dan Semester (\%)

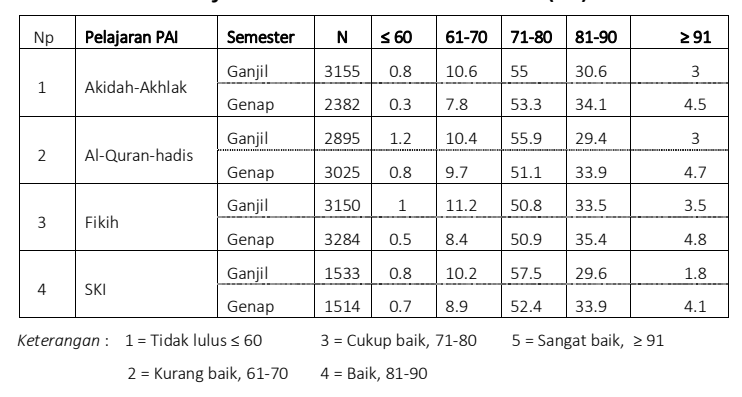

\section{Hasil Capaian Afektif}

Hasil capaian afektif siswa MA ini terukur dari beberapa dimensi pelajaran PAI yang secara teoritis telah dijelaskan sebelumnya. Ada lima rumpun bidang isu pelajaran PAI yang dianalisis, yaitu (a) sikap terhadap etika teologis relasi lintas agama, (b) sikap terhadap etika sosial relasi lintas agama, (c) sikap terhadap wacana formalisasi hukum Islam dalam tata kehidupan bernegara dan bermasyarakat, (d) dukungan terhadap doktrin jihad berbasis kekerasan, dan (e) dukungan terhadap prinsip demokrasi. Score maksimal untuk setiap rumpun bidang yang dianalisis ini direntang dari 1-7. Indikator untuk dua rumpun dimaksud dikonstruksi dengan model pernyataan negatif, kecuali untuk rumpun masalah Fikih dan politik hukum Islam dan demokrasi yang dirumuskan dalam redaksi positif.

Grafik 1: Sikap (Capaian Afektif) Siswa terhadap Etika Teologis Relasi Lintas Agama

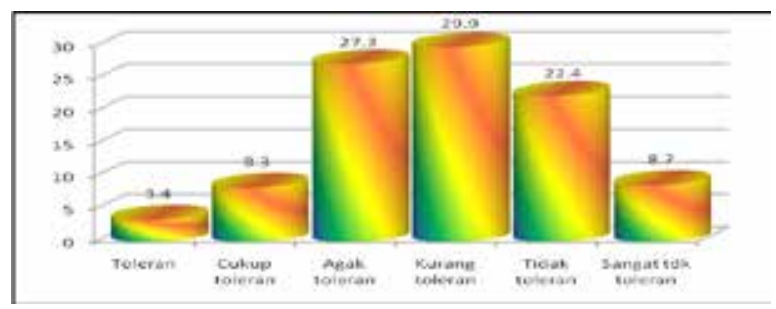

$\mathrm{N}=2.961 \quad$ Mean $=4.85 \quad \mathrm{Std}=1.22$

Min $=1 \quad$ Maks $=7$

Grafik 1 menunjukkan bahwa sikap siswa terhadap etika teologis relasi lintas agama masih cenderung kurang toleran. Secara umum, tingkat capaian afektif pada materi etika teologis relasi lintas agama masih sangat cenderung negatif terhadap non muslim, yaitu dengan score rata-rata 4.85 (dari skala maksimal 7) atau setara dengan Kurang Toleran. Rinciannya bahwa 31.1 \% responden menolak (tidak toleran), atau menolak untuk bersikap terbuka, inklusif dengan hati yang rela untuk menerima kepentingan umat non muslim. Hanya 11.7 \% responden yang cenderung bersikap positif, toleran pada kepentingan non muslim dalam relasi teologis. Ringkasnya, tingkat capaian afektif di bidang ini masih sangat rendah, jika diukur dari standar target ideal pembelajaran sebagai materi ajar AkidahAkhlak. Di sini proses pembelajaran PAI pada materi ajar belum mampu menanamkan secara positif sikap toleran, inklusif dan terbuka terhadap kehadiran non muslim. 
Pada aspek ini menunjukkan bahwa proses pembelajaran PAI dalam konteks etika teologis relasi lintas agama terbukti belum mampu mencapai hasil maksimal, bahkan masih cenderung belum mampu mencapai batas wajar capaian afektif. Hal ini harus betulbetul disadari oleh para guru Akidah-Akhlak. Di sini, pembelajaran materi toleransi dalam pelajaan Akidah-Akhlak masih belum mampu membentuk sikap positif siswa kepada non muslim; para siswa belum mampu memberi, menciptakan siswa ruang batin yang positif pada model relasi kerukunan yang ramah, dan terbuka untuk menerima kehadiran orang-orang yang berbeda keyakinan atau agama dalam lingkup kehidupannya

Grafik 2

Sikap (Capaian Afektif) Siswa terhadap Etika Sosial Relasi Lintas Agama (Toleransi)

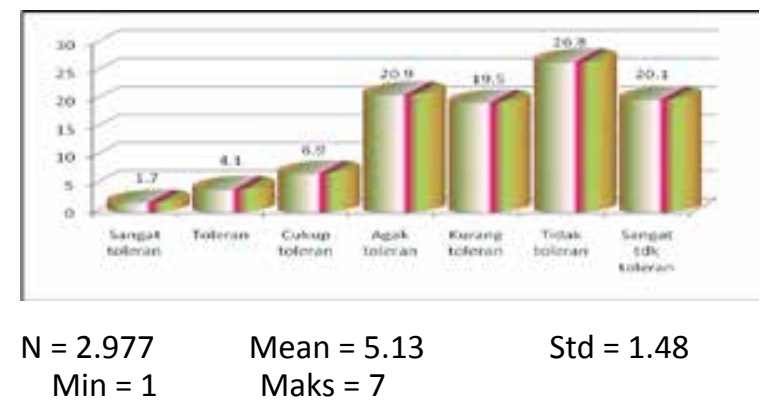

Grafik 2 menunjukkan bahwa sikap siswa terhadap etika sosial relasi lintas agama juga masih sangat cenderung tertutup. Secara umum, tingkat capaian afektif pada materi etika sosial relasi lintas agama masih sangat cenderung negatif terhadap non muslim, yaitu dengan rata-rata score 5.13 atau setara dengan Tidak Toleran. Rinciannya bahwa 20.1 $\%$ responden sangat menolak (sangat tidak toleran), dan $26.8 \%$ lainnnya menolak untuk bersikap terbuka, dengan hati yang rela untuk menerima kepentingan non muslim. Hanya $12.7 \%$ responden siswa yang cenderung bersikap positif, toleran kepada non muslim dalam relasi sosial. Ringkasnya, tingkat capaian afektif di bidang ini masih sangat rendah. Di sini proses pembelajaran PAI pada materi ajar etika sosial relasilintas agama belum mampu menanamkan secara hakiki sikap toleran, inklusif dan terbuka terhadap kehadiran non muslim. Dengan kata lain, siswa MA masih tidak positif menyikap hak-hak dan kepentingan non Islam, terutama pada lima indikator etika sosial relasi lintas agama. Siswa MA lebih cenderung tidak memberi ruang dan kelonggaran yang lebih pada model relasi yang lebih inklusif dalam interaksi lintas agama di kehidupan sehari-hari. Alhasil, resistensi siswa terhadap ajaran PAI yang mengajarkan keramahan lintas agama dalam bingkai perbedaan keyakinan dan keragaman sosial keagamaan masih sangat perlu diperhatikan.

\section{Grafik 3}

Sikap (Capaian Afektif) Siswa terhadap Doktrin Jihad Berbasis Kekerasan

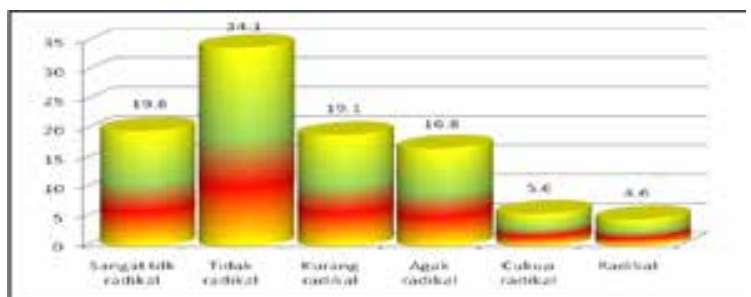

$\mathrm{N}=3.174 \quad$ Mean $=2.59$

Min = 1

Std $=1.38$

Maks $=7$

Grafik 3 menunjukkan bahwa responden masih cukup mendukung ajaran jihad yang berbasis kekerasan. Artinya, pembelajaran PAI pada bidang ajar al-Quran-Hadis dalam pewacanaan jihad yang ramah, elegan, yang menolak cara-cara kekerasan dalam membela Islam masih belum mendapat dukungan maksimal dari responden. Walaupun ratarata capaian sikap sudah mencapai skala 2.59 (setara dengan Kurang Radikal), namun, minimal $27 \%$ responden siswa tetap cenderung mendukung doktrin jihad Islam berbasis kekerasan dimaksud.

Fakta ini menyisakan pertanyaan penting, yaitu faktor apa yang berperan dominan dalam membentuk sikap radikal dalam membela Islam. Hal ini penting mengingat salah satu tujuan dasar pembelajaran al-Quran-Hadis adalah usaha untuk menjelaskan konsep jihad 
yang relavan dengan konteks keindonesiaan. Gejala dukungan terhadap doktrin jihad berbasis kekerasanini dapat dijadikan indikator oleh kelompok tertentu yang menyimpulkan bahwa basis dan benih radikalisme juga mengakar kuat sikap siswa MA. Fenomena ini harus mendapat perhatian dari para praktisi pendidikan Islam, pemuka agama, dan para pemangku kebijakan pengembangan PAI.

Grafik 4

Sikap (Capaian Afektif) Siswa terhadap Wacana Formalisasi Hukum Islam

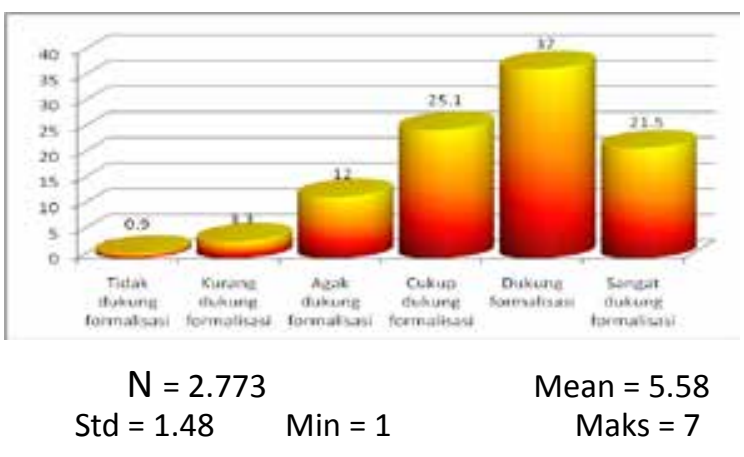

Grafik 4 memperlihatkan bahwa responden sangat mendukung gagasan penerapan hukum Islam (dalam format formal) dengan score ratarata 5.58 (setera dengan sikap positif mendukung usaha formalisasi). Bahkan kecenderungan ini relatif merata di kalangan responden yang terukur dengan angka standar deviasi. Ringkasnya, dari fakta ini dapat disimpulkan bahwa pembelajaran PAI pada bidang ajar Fikih telah cukup mampu mencapai target ideal dari capaian afektif. Artinya, guru-guru Fikih terbukti berhasil menanamkan sikap dukungan pada siswa pada urgensitas penerapan hukum Islam dalam kehidupan sehari-hari.

Apakah trend capaian afektif yang positif juga sejalan dengan capaian pada sikap terhadap wacana demokrasi. Salah satu materi ajar al-Quran dan Hadis mengajarkan prinsip demokrasi. Bahkan pada bagian itu, dijelaskan bahwa Islam tidak menolak demokrasi, terutama pada pengakuan rule of law, Allah tidak pilih kasih pada hamba-Nya yang berbuat baik, dan konsep kesetaraan umat manusia dalam konteks ranah kehidupan sosial.

Grafik 5

Sikap (Capaian Afektif) Siswa terhadap Etika Demokrasi

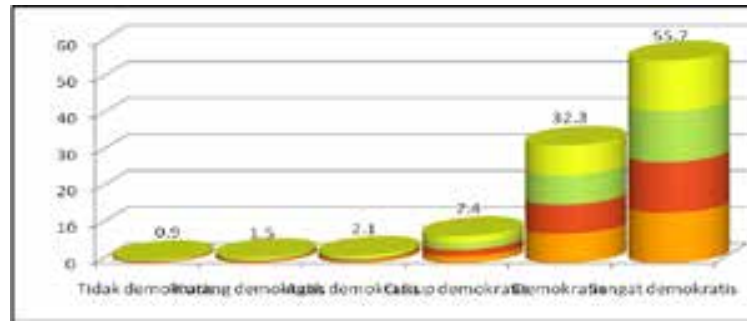

$\mathrm{N}=3.302$

Mean $=6.35$

Std $=0.94$

Min $=1$

Maks $=7$

Grafik 5 membuktikan bahwa sikap kecenderungan siswa mendukung gagasan demokrasi sangat tinggi. Bahkan score ratarata dukungan mencapai 6.35, nyaris sempurna, dengan tingkat standar deviasi yang sangat rendah. Namun demikian, masih ada sekitar $4 \%$ responden siswa yang tidak positif dalam menyikapi wacana demokrasi. Ringkasnya, proses dan misi pembelajaran PAI dalam bidang ajar isu demokrasi sudah dapat mencapai hasil yang sangat positif. Bahkan capaian afektif untuk bidang ini adalah hasil capaian yang paling tinggi dari hari pembelajaran seluruh materi ajaran PAI. Dari keseluruhan data tentang hasil capaian afektif di atas dapat disimpulkan sebagai berikut:

1) Tingkat hasil capaian afektif pembelajaran PAI bervariasi menurut bidang ajarnya. Hasil capaian afektif sudah sangat baik pada bidang ajar yang tidak terlalu menyentuh aspek keyakinan keagamaan, seperti pada kasus materi ajar tentang wacana demokrasi dan penerapan hukum Islam dalam kehidupan sehari-hari.

2) Tingkat capaian afektif pada materi ajar yang bersentuhan dengan prinsip dan keyakinan keagamaan, relatif masih sangat rendah. Sikap responden cenderung tidak, minimal kurang toleran dalam konteks 
relasi lintas agama, baik pada aspek relasi yang lebih sosial, atau pada relasi yang berisan dengan faktor teologi.

3) Dengan kata lain, ada dua model capaian afektif hasil pembelajaran PAI di MA. Kenyataan ini mengisyaratkan bahwa ada faktor yang mempengaruhi keberhasilan capaian afektif hasil pembelajaran PAI.

\section{Hasil Capaian Psikomotorik}

Bagaimana capaian psikomotorik pembelajaran PAI di MA? Beberapa Grafik berikut menyajikan data untuk menjawab pertanyaan di atas. Aspek capaian psikomotorik dipilah ke dalam tiga faktor, yaitu aspek perilaku ritual (pelaksanaan ibadat konvensional, cenderung ibadat ghairu mahdlah), aspek perilaku ketaatan-penyimpangan prinsip moral-susila, dan perilaku sosial.

\section{Grafik 6}

Capaian Psikomotirik Pembelajaran PAI Aspek Pelaksanaan Ibadat Konvensional

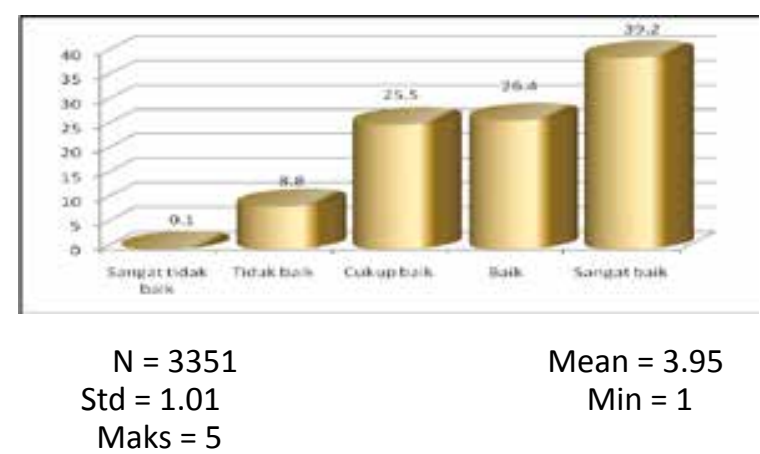

Grafik 6 di atas menyajikan data tentang hasil capaian psikomotorik pada bidang pelaskanaan ibadat konvensional yang terdiri atas unsur ibadat membaca al-Quran, puasa sunat, salat dluha, salat tahajjud, salat rawatib, salat witir di luar bulan puasa, dan salat berjamaah. Tingkat hasil capaian psikomotorik dalam hal pelaksanaan ibadat konvensional sangat baik. Lebih dari sepertiga responden rutin melaksanakan secara maksimal menurut standar normatif Islam, seperti pelaksanaanya harian, atau mingguan. Namun demikian, masih ada minimal sekitar $9 \%$ responden mengaku tidak pernah mengerjakan kegiatan ibadat dimaksud minimal sekali sebulan.

\section{Grafik 7}

Capaian Psikomotirik Pembelajaran PAI Aspek Perilaku Moral-Susila

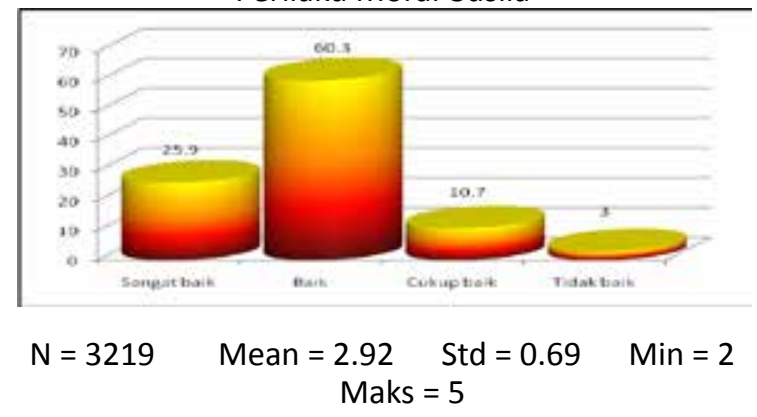

Grafik 7 di atas menyajikan data tentang capaian psikomotorik pada bidang perilaku moral-susila. Indikator perilaku moral-susila ini mencakup pengalaman berpacaran dan tindakan buruk yang pernah dilakukan saat pacaran, mulai dari bergandengan tangan sampai menyentuh baik tubuh pacaran yang sensitif, atau identik dengan bagian reproduktif. Secara keseluruhan perilaku moral-susila responden MA masih baik. Walaupun perilaku pacaran juga dilakoni oleh siswa MA, namun gaya pacaran mereka masih relatif normatif jika dibanding dengan gaya pacaran dan seks bebas di kalangan siswa SLTA yang pernah dipetakan dalam sejumlah penelitian lain, seperti survei BKKBN mencatat bahwa sekitar separo siswa SLTA di Jakarta mengaku sudah pernah mempraktekkan seks bebas.

Walaupun hasil capaian bidang perilaku moral-susila sudah sangat baik, namun sekelompok siswa yang melakukan penyimpangan moral-susila harus mendapat catatan. Minimal sekitar $3 \%$ responden mengaku pernah melakukan tindakan tidak terpuji saat berpacaran, paling tidak 2-3 kali selama hidupnya. Potret wajah cacat ini harus mendapat perhatian para praktisi pendidikan Islam, terutama untuk mengawal lebih intensif lagi perilaku buruk siswa dalam konteks pelanggaran moral-susila. 
Grafik 8

Capaian Psikomotirik Pembelajaran PAI Aspek Perilaku Sosial

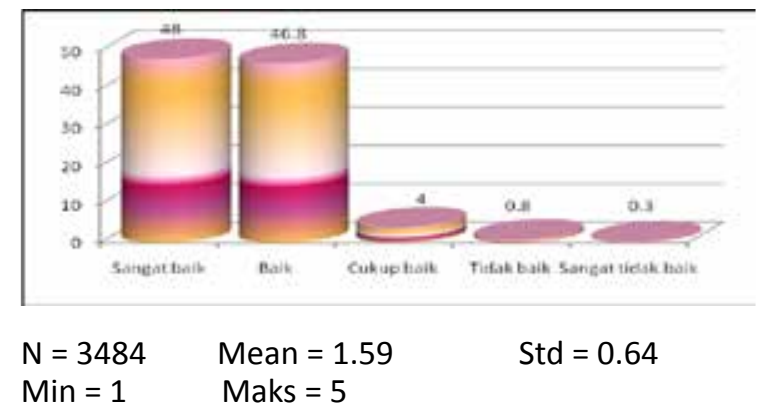

Grafik 8 di atas menyajikan data tentang capaian psikomotorik pada bidang perilaku sosial. Tingkat capaian psiko-motorik bidang ini sudah sangat positif, sangat baik. Lebih dari $95 \%$ responden mengaku tidak pernah, atau hanya sekali melakukan perilaku buruk seperti yang ditanyakan dalam penelitian ini, kecuali pada aspek mengunduh gambar porno atau menonton film porno. Bahkan kecenderungan perilaku positif ini sangat merata di kalangan responden, yang hal ini ditunjukkan oleh angka standar deviasi. Namun fenomena detail tentang penyimpangan seperti yang disajikan pada beberapa tabel di lampiran makalah ini, tidak boleh membuat pelaku pendidikan Islam lupa diri. Pekerjaan rumah guru PAI masih ada untuk membenahi lubang-lubang keberhasilan pelajaranan PAI.

Bagaimana capaian psikomotorik pada perilaku sosial-keagamaan lainnya? Pertama, pengalaman siswa mendalami ajaran Islam secara khusus, dan pribadi, di luar prigram resmi MA, sangat tinggi. Minimal $17 \%$ siswa MAN dan $24.7 \%$ siswa MAS pernah mendalami ajaran Islam secara khusus selama sekolah di MA. Ini sebuah potensi yang cukup positif untuk optimalisasi pembinaan perilaku keagamaan peserta didik MA.

Kedua, pengalaman siswa MA berguru khusus pada sosok ulama tertentu untuk menimba ilmu agama sangat menarik. Hanya 53.2 \% siswa MAN dan $52.8 \%$ siswa MAS mengaku tidak pernah berguru khusus kepada tokoh agama tertentu untuk menimba ilmu agama. Ini satu capaian yang baik, dan harus dibina, dikelola lebih baik dalam pendidikan agama Islam pada peserta didik di MA.

Ketiga, pengalaman siswa MA mengikuti kegiatan kelompok dzikir juga cukup positif. Dalam hal ini, $23.8 \%$ siswa MAN dan $26.9 \%$ siswa MAS mengaku pernah ikut kegiatan kelompok dzikir di luar kegiatan terstruktur yang dilakukan oleh MA tempat dia bersekolah.

Keempat, pengalaman siswa mengikuti kegiatan kelompok Islam garis keras dalam melakukan tindakan penyerangan terhadap umat agama lain menarik untuk dikritisi. Ada 2.8 $\%$ siswa MAN dan $2.6 \%$ siswa MAS yang mengaku tidak pernah ikut kegiatan kelompok Islam garis keras dalam melakukan penyerangan terhadap agama-umat lain. Ini satu fenomena radikalisme di kalangan siswa MA. Benih pengalaman ini bisa berkembang di level pendidikan tinggi, jika mantan siswa ini tidak dibina dengan baik.

\section{Faktor-Faktor yang Mempengaruhi Hasil Capaian Pembelajaran PAI}

Bagian ini akan mendiskusikan faktorfaktor yang mempengaruhi hasil capaian pembelajaran PAI. Pemaparan hasil capaian di sini akan diurut seperti pembahasan sebelumnya, mulia dari ranah kognitif, afektif dan psikomotir.

Pertama, seperti telah disinggung sebelumnya, capaian kognitif (nilai siswa per mata pelajaran PAI secara signifikan dipengaruhi oleh status (kualitas) MA. Prestasi, atau nilai siswa MAN dan MA yang terakreditasi selalu lebih tinggi dibanding prestasi belajar siswa MAS atau MA yang belum terakreditasi, dan atau MA yang standar terakreditasi lebih rendah. Dengan kata lain, faktor kualitas MA sangat menentukan tingkat capaian kognitif siswa dalam proses pembelajaran PAI di MA.

Kedua, temuan capaian pada ranah afektif sangat menarik. Sejumlah faktor (variabel) berpengaruh secara signifikan terhadap tingkat capaian afektif menurut bidang materi ajar PAI yang dicermati. Apakah hasil capaian 
afektif siswa dalam pembelajaran PAI berkorelasi secara positif dengan beberapa variabel atribut pedagogik guru PAI. Analisis korelasi menunjukan bahwa faktor perilaku pedagogik guru tidak berkorelasi, dan juga tidak berpengaruh secara signifikan terhadap pembentukan sikap siswa pada lima aspek materi ajar PAI yang diteliti, yaitu sikap terhadap etika sosial dan teologis lintas agama, dukungan terhadap formalisasi penelitan hukum Islam, dukungan terhadap wacana demokrasi, dan dukungan terhadap konsep jihad yang bernuansa kekerasan.

Hubungan antara Beberapa Variabel Atribut Pedagogik Guru PAI dengan Hasil Capaian Afektif Siswa dalam Pembelajaran PAI mengindikasi beberapa aspek berikut. (a) Intensitas guru menggunakan media dan sumber belajar, dan intensitas pengelolaan kelas oleh guru saat mengajar hanya berkorelasi signifikan dengan sikap siswa terhadap wacana formalisasi hukum Islam di ranah kehidupan bernegara dan bermasyarakat. (b) Intensitas penggunan strategi pembelajaran berkorelasi signifikan dengan dukungan terhadap etika teologis dan sosial relasi lintas agama, dukungan terhadap konsep jihad yang berbasis kekerasan, serta dukungan terhadap wacana demokrasi. (c) Intensitas guru melakukan evaluasi dan penerapan implikasinya hanya berkorelasi signifikan dengan sikap terhadap etika sosial lintas agama, dan dukungan terhadap wacana demokrasi. (d) Intensitas guru PAI melakukan pembinaan karakter siswa berkorelasi signifikan dengan dukungan terhadap wacana formalisasi hukum Islam di Indonesia.

Walaupun dalam beberapa kasus signifikan, korelasi perilaku pedagogik guru PAI dengan beberapa aspek yang dianalisis hanya berkorelasi sangat lemah, yaitu selalu di bawah 0.1. Ini artinya bahwa keragaman tingkat capaian afektif hasil pembelajaran PAI di MA tidak begitu akurat dijelaskan dengan variabel perilaku pedagogik guru PAI. Ringkasnya, faktor perilaku pedagogik guru tidak begitu bermakna untuk mengkritisi besar pengaruhnya terhadap hasil capaian afektif pembelajaran PAI. Dengan kata lain, tingkat capaian afektif siswa MA di bidang pembelajaran PAI tidak banyak dipengaruhi oleh faktor perilaku pedagogik guru PAI. Temuan juga ini mengisyaratkan bahwa faktor yang lebih determinan dalam membentuk hasil capaian afektif pembelajaran PAI siswa berada di luar kerangka kegiatan proses belajarmengajar dan atribut pada guru PAI itu sendiri. Faktor-faktor non kependidikan, dan faktor luar sekolah nampaknya lebih menentukan hasil capaian afektif.

Apakah capaian afektif siswa dipengaruhi oleh atribut sikap dan cara pandang keagamaan para guru PAI? Hubungan antara beberapa variabel Sikap Keagamaan Guru PAI dengan Hasil Capaian Afektif Siswa dalam Pembelajaran PAI menunjukkan tentang korelasi ini. Hampir seluruh aspek sikap keagamaan guru berkorelasi signifikan dengan beberapa hasil capaian afektif siswa dalam proses pembelajaran PAI. Sikap radikal keagamaan guru tidak berkorelasi positif dan signifikan dengan hasil capaian afektif aspek dukungan terhadap etika sosial dan teologis. Seperti halnya dengan fungsi perilaku pedagogik guru, korelasi seuruh faktor sikap keagamaan guru, walaupun signifikan, hanya sangat lemah dengan hasil capaian afektif pembelajaran PAI di MA. Dengan kata lain, hasil capaian afektif pembelajaran PAI tidak banyak dipengaruhi oleh sikap keagamaan guru PAI.

Pengaruh guru terhadap sikap dukungan siswa pada beberapa aspek yang dianalisis bervariasi secara signifikan. Secara keseluruhan bahwa perbedaan pengaruh-peran guru PAI dalam menanamkan sikap keagamaan (capaian afektif) terbukti hanya berbeda secara signifikan pada dimensi etika teologis dan sosial relasi lintas dan dukungan pada wacana formalisasi hukum Islam di Indonesia. Pada ketiga dimensi lainnya, pengaruh guru PAI, apapun mata pelajaran yang diajarkan tidak terbukti berpengaruh signifikan terhadap hasil capaian afektif pembela-jaran PAI. Ini artinya bahwa keberhasilan penanaman semangat etis terhadap materi ajar pelajaran PAI 
pada etika teologis dan sosial relasi lintas dan dukungan pada wacana formalisasi hukum Islam di Indonesia, sangat terkait erat dengan latar belakang guru bidang pelajaran tertentu. Di sini, guru bidang pelajaran SKI dan al-Quran-Hadis cenderung tidak terlalu berhasil menanamkan nilai-nilai etis relasi lintas agama.

Jika variabel perilaku pedagogik guru dan sikap keagamaannya tidak berkorela kuat dengan capaian hasil afektif pembelajaran PAI, lalu apakah faktor atau variabel lain (kontrol) justru sangat mempengaruhi capaian hasil pembelajaran PAI? Hubungan antara Beberapa Variabel Sikap Keagamaan Guru PAI dengan Hasil Capaian AfektifSiswa dalam Pembelajaran PAI (Korelasi Parsial dengan Sistem Pengelolaan Siswa) menunjukkan tentang korelasi atribut keagamaan guru dengan hasil capaian afektif siswa pembelajaran PAI saat dikontrol dengan variabel sistem pengelolaan siswa. Berdasarkan data hasil korelasi, tidak ada satu faktor atribut atau sikap keagamaan guru yang berkorelasi signifikan dengan hasil capaian afektif. Dengan kata lain, faktor sistem pengelolaan siswa dalam format diasramakan dan tidak, sangat berpengaruh terhadap hasil capaian afektif siswa. Ringkasnya, sistem asrama sangat berpengaruh terhadap capaian afektif pembelajaran PAI. Oleh sebab itu, pengelolaan siswa dalam sistem asrama sangat penting untuk memaksimalisasi hasil capaian pembelajaran PAI.

Apakah hasil capaian psikomotorik dipengaruhi oleh sejumlah variabel lain, yaitu pola asuh orangtua di keluarga? Hasil penelitian menunjukkan bahwa ada korelasi antara pola asuh orangtua dalam keluarga dengan hasil capaian psikomotorik dalam pembelajaran PAI. Perilaku ritual (pelaksanaan ibadat) berkorelasi positif, signifikan, dan relatif kuat dengan sejumlah model pola asuh keagamaan dan sosial orangtua di keluarga. Secara spesifik, umpama, faktor pembiasaan beribadat (salat berjamaah, dan melaksanakan kegiatan keagamaan lainnya) dalam keluarga berkorelasi signifikan dengan tingkat capaian psikomotorik hasil pembelajaran PAI di MA.

Korelasi antara Pola Asuh-Pembinaan Karakter Keagamaan di Keluarga dengan Hasil Capaian Psikomotorik Siswa dalam Pembelajaran PAI menunjukkan bahwa tingkat keberhasilan pembelajaran PAI di ranah psikomotorik jauh lebih dipengaruhi oleh pola asuh sosial-keagamaan orangtua dalam keluarga. Temuan ini sejalan dengan temuaan sebelumnya yang menunjukkan bahwa sistem asrama berpengaruh signifikan terhadap hasil capaian afektif. Sebetulnya, efek minimal proses kegiatan belajar-mengajar (KBM) dalam pembentukan sikap dan perilaku keagamaan peserta didik di bidang pelajaran PAI sangat masuk akal. Pertama, waktu pembinaan keagamaan siswa di MA sangat terbatas. Kedua, bahkan hubungan guru dengan siswa dalam pembinaan keagamaan siswa cenderung sangat bersifat formal, kurang menyentuh relasi emosional yang menjadi prasyarat pencapaian lebih maksimal hasil dalam pembentukan karakter, sikap dan perilaku keagamaan siswa. Akhirnya dalam pola relasi seperti ini, fungsi guru PAI hanya sebatas penyampai informasi, ilmu bidang agama Islam, tetapi tidak sampai menyentuh dominan pembentukan watak keagamaan peserta didik. Dengan kata lain, fungsi guru PAI dalam pembentukan sikap dan perilaku keagamaan peserta didik hanya terhenti pada perannya sebagai penyampai informasi, ilmu di bidang agama Islam.

Sebaliknya, pengaruh positif pola asuh sosial-keagamaan orangtua di keluarga tidak hanya terbatas pada aspek perilaku ritual keagamaan siswa, tetapi juga menyentuh dimensi perilaku moral-susila dan sosial. Siswa yang diasuh oleh orangtua yang penuh perhatian atau ketat dalam kontrol pembinaan sosial, moral keagamaan anak-anaknya, juga terbukti dapat menekan perilaku menyimpang anak-anaknya. 


\section{PENUTUP}

\section{Kesimpulan}

Dari hasil temuan di atas, ada beberapa kesimpulan dari penelitian ini.

1. Hasil capaian kognitif siswa MA dalam pembelajaran PAI relatif sudah cukup baik. Rata-rata nilai untuk seluruh mata pelajaran selalu di atas 78 point dari score maksimal 100. Namun demikian, masih ada sejumlah siswa dengan capaian di bawah standar kelulusan.

2. Capaian afektif siswa pada pelajaran PAI memperlihatkan fenomena menarik. Salah satu tujuan utama pembelajaran PAI adalah penanaman nilai-nilai luhur agama seperti menghargai perbedaan, menjaga kesantuan dan bersikap ramah dan inklusif pada orang yang berbeda agama. Hasil penelitian ini menunjukkan hasil capaian afektif pada bidang-bidang penanaman nilai-nilai luhur dalam kehidupan relasi lintas agama dalam konteks bermasyarakat, berbangsa dan bernegara dalam keragaman agama masih sangat perlu mendapat perhatian. Di sini, apresiasi terhadap nilai-nilai etis teologis, juga sosial relasi lintas agama masih sangat perlu mendapat pembinaan serius, minimal lebih intensif. Tingkat penolakan atau resistensi terhadap interaksi dengan umat yang berbeda agama sangat tinggi. Capaian afektif pada penanaman nilainilai santun dalam beragama, terutama dalam penyiaran agama juga masih sangat rendah. Mayoritas siswa masih lebih affirmatif dengan konsep jihad berbasis kekerasan. Karenanya, fungsi pengajaran materi toleransi, dan penghargaan terhadap keragaman latar belakang agama di masyarakat masih belum menyentuh sasaran pembentuk watak toleran dalam relasi lintas agama. Nampaknya faktor pengalaman ekspose pada hidup dalam keragaman penganut agama menjadi faktor penghambat pencapaian afektif ini dalam penanaman sikap ramah terhadap umat lain di luar Islam.
3. Hasil capaian psikomotorik untuk pembelajaran PAI sudah cukup baik. Siswasiswa MA sudah mampu dengan intensitas cukup tinggi dalam menjalankan perintah agama dalam beribadat. Untuk aktivitas keagamaan konvensional, tingkat capaian psikomotorik sangat positif. Tetapi di sisi lain, perilaku tercela siswa MA juga masih cukup memprihatikan. Fenomena siswa MA mencoba ragam obat-obatan terlarang, pengalaman mengkonsumsi minuman keras, perilaku pacaran yang sudah melampaui batas etika moral, susila serta kesopanan adat perlu mendapatkan perhatian. Walaupun intensitasnya masih jauh di bawah fakta statistik yang terjadi pada siswa SLTA di Jakarta, dan di beberapa provinsi lainnya, namun fenomena gaya pacaran anak MA sudah menunjukkan tanda-tanda yang siap menuju ke arah kekhawatiran banyak orangtua. Temuan studi ini pada bidang capaian psikomotorik dalam konteks gaya pacaran tidak boleh disikapi secara emosional. Pola asuh sosialkeagamaan orangtua di keluarga dapat menekankan perilaku negatif siswa dari perilaku menyimpang.

4. Variabel sikap keagamaan guru PAI tidak berpengaruh banyak dalam pembentukan sikap keagamaan siswa. Bahkan uji statistik inferensial menunjukkan bahwa fungsi kausalistik sikap keagamaan guru PAI nyaris tidak bermakna secara maksimal. Faktanya bahwa harapan banyak orangtua agar anak-anaknya memiliki sikap dan perilaku keagamaan yang santun ternyata banyak "terpenuhi". Ini satu wujud raport buruk PAI di mata sejumlah wali murid MA. Variabel perilaku pedagogik guru MA saat mengajar materi PAI juga tidak terbukti berpengaruh signifikan terhadap hasil capaian afektif pembelajaran PAI. Jika korelasi hasil capaian dan perilaku pedagogik guru PAI dan sikap keagamaan guru terbukti signifikan, namun besaran pengaruh variabel-variabel ini terbukti sangat kecil, minor dalam membentuk sikap keagamaan siswa yang diajarkan dalam materi ajar PAI. 


\section{Rekomendasi}

Berdasarkan hasil temuan di atas, maka penelitian ini merekomendasikan beberapa hal untuk peningkatan fungsi pembelajaran PAI untuk pembentukan sikap dan karakter keagamaan siswa.

1. Rendahnya fungsi guru PAI dalam pembentukan capaian afektif dan psikomotorik sosial-keagamaan peserta didik di MA menjadi pintu pembuka untuk rekomedasi yang disarankan. Minimnya fungsi guru dalam pembentukan sikap dan perilaku keagamaan di atas, nampaknya, menjadi petanda kuat bahwa peran guru dalam proses pembelajaran PAI lebih dominan hanya sebatas fungsi mengajar, tidak sampai ke tahap mendidik untuk pembentukan karaktek peserta didik. Oleh karena itu, para guru PAI di MA harus lebih menekankan fungsi edukatif untuk pembentukan karakter dan perilaku keagamaan siswa. Fungsi guru sebatas mengajar tidak cukup mampu membentuk sikap dan perilaku keagamaan.

2. Ketika proses kegiatan pengajaran dan perilaku pedagogik guru PAI cukup berperan dalam pembentukan watak keagamaan peserta didik, hal itu nampaknya diakibatkan oleh pola relasi siswa-guru yang terlalu distrukturisasi dalam bingkai relasi formal, bahkan dalam format penilaian hasil pembelajaran secara formal. Guru scara tradisional lebih berfungsi sebagai atasan, yang menjaga jarak emosional dan sosial dengan siswa. Akhirnya, terbentuk jarak emosional dan sosial yang lemah antara guru dan murid. Oleh sebab itu, pembinaan sikap dan perilaku keagamaan siswa, nampaknya, akan lebih fungsional jika guru lebih mampu membangun relasi yang lebih cair, lebih inklusif, lebih emosional dengan para peserta didiknya, dengan menekankan dimensi simpati dan empati dalam pembelajaran PAI. Keakraban guru secara emosional dan sosial dapat membuka dan mendorong siswa keinginan untuk terlibat lebih banyak dalam pembinaan keagamaan yang diasuh oleh para guru PAI.

3. Evaluasi hasil pembelajaran PAI selama ini masih terlalu menekankan aspek capaian kognitif. Akibatnya, penilaian dimensi sikap dan perilaku keagamaan kurang mendapat perhatian dalam penilaian hasil belajar. Mayoritas responden guru dalam penelitian ini mengusulkan formula ideal untuk model evaluasi hasil pembelajaran PAI. Mayoritas guru PAI menyarankan agar model penilaian hasil belajar PAI cenderung mengurangi porsi capaian kognitif, hanya sebatas di bawah 40 persen. Selebihnya, penilaian hasil belajar PAI harus lebih banyak mengakomodasi capaian afektif dan psiko-motorik, minimal masing-masing sebesar 30 persen.

4. Rekomendasi butir 3 di atas berimplikasi pada pertimbangan lain. Para guru PAI harus lebih menyadari keterbatasan waktu mereka dalam bergaul dengan para siswa untuk membina sikap dan perilaku keagamaannya. Oleh karena itu, pelibatan orangtua siswa dalam pengawasan sikap dan perilaku para siswa harus lebih dioptimalisasi. Buku catatan penghubung antara fungsi orangtua di rumah dan fungsi guru PAI di madrasah nampaknya menjadi satu pilihan menarik untuk dicoba guna mendorong agar hasil capaian pembelajaran PAI di ranah afektif dan psikomotorik dapat digapai secara lebih maksimal.

5. Ketika perilaku pedagogik konvensional guru bahkan dalam format yang lebih inovatif tidak begitu berpengaruh terhadap pembentuk sikap dan perilaku keagamaan peserta didik, maka para guru PAI harus lebih berinisiatif dan inovatif untuk menggagas model pembelajaran yang lebih fungsional dalam mencapai target maksimal tujuan pembelajaran agama. Selama ini, secara umum, model pengajaran mayoritas guru PAI terlalu banyak terkooptasi pada pola pengajaran yang sangat tradisional, konvensional, yang lebih menekankan aspek pengajaran monolog, ceramah, 
ketimbang fungsi pendidikan yang lebih kreatif, inovatif, dan lebih berorientasi pada kepentingan siswa untuk pembentukan karakter sikap dan perilaku keagamaannya. Oleh sebab itu, pelibatan para guru PAI dalam pelatihan peningkatan kemampuan pedagogis dan kapasitasnya sebagai pendidik harus diprioritaskan dalam pembuatan kebijakan pembinaan karir guru PAI, terutama guru-guru PAI di MAS. Hasil penelitian ini menunjukkan bahwa mayoritas responden guru PAI di sini tidak pernah mengikuti pelatihan ketrampilan di bidang kependidikan dari Kementerian Agama. Ini sesuatu yang ironis.

\section{SUMBER BACAAN}

Alim, Muhammad (2006): Pendidikan Agama Islam, Upaya Pembentukan Pemikiran dan Kepribadian Muslim. Bandung, PT Remaja Rosdakarya.

Arifin, M. (1991): Kapita Selekta Pendidikan (Islam dan Umum). Jakarta: Bumi Aksara.

Azizy, A. Qodri (2000): Islam dan Permasalahan Sosial: Mencari Jalan Keluar. Yogjakarta, Pustaka Pelajar.

Bawani, Imam (1993): Ilmu Pendidikan Islam, Jakarta, Bumi Aksara.
Daulay, Haidar Putra (2004): Pendidikan Islam, Jakarta, Kencana.

Departemen Pendidikan Nasional (2002): Kurikulum dan Hasil Belajar Kompetensi Dasar Mata Pelajaran Agama Islam di Sekolah Menengah Atas dan Madrasah Aliyah. Jakarta, Pusat Kurikulum, Balitbang, Depdiknas.

Khodijah, Nyayu (2009): "Peningkatan Keberhasilan Pembelajaran PAI di SMA dengan Pendekatan Belajar Reflektif', Jurnal Teknologi Pendidikan, Vol 9, No. 3.

Khodijah, Nyayu (2009): "Peningkatan Keberhasilan Pembelajaran Pendidikan Agama Islam (PAI) dengan Pendekatan Reflective Learning", Jurnal Pembangunan Manusia, Vol. 7 (1).

Mukhtar (2003): Desain Pembelajaran Pendidikan Agama Islam. Jakarta, Miska Galiza.

Sahertian, P.A. (2000), Konsep Dasar dan Teknik Supervisi Pendidikan. Jakara, Rineka Cipta.

Simamora, Bilson (2005): Analisis Multivariat Pemasaran. Jakarta, Gramedia Pustaka Utama.

Zuhairini (1983): Metodik Khusus Pendidikan Agama. Surabaya, Usaha Nasional. 